\title{
Chapter 16 \\ Diaspora Policies, Consular Services and Social Protection for Italian Citizens Abroad
}

\author{
Carlo Caldarini
}

\subsection{Introduction}

The Italian diaspora is a large-scale historical phenomenon that has involved millions of people for about a century and a half. Except for the fascist era, the Italian authorities have always demonstrated an interest in the phenomenon of emigration, and have even tried to regulate and support it. For example, the Government has, at given times, subsidized travel expenses, ensured repatriation, banned emigration to certain countries during pestilences, and subsidized the cost of some Italian charities, schools and hospitals abroad (Foerster 1919; Murat et al. 2008).

Italy was also the first country in the world to promote a bilateral agreement, in the early 1900s, aimed at guaranteeing acceptable living and working standards for their emigrants working abroad (Caldarini 2014). ${ }^{1}$ But how is the situation today? This chapter presents the main features of current Italian diaspora policies, especially in the area of social protection. After briefly presenting some basic figures regarding the history of Italian emigration, the first section discusses the institutional framework by which Italian authorities interact today with their nationals abroad, as well as the main policies of engagement with non-resident citizens in areas that are not directly related to social protection (e.g. education, electoral rights, etc.). The second section provides descriptive information about the policies and services offered by Italian authorities to respond to the social protection needs of nationals abroad across five specific policy areas: unemployment, health care, pensions,

${ }^{1}$ Convenzione fra l'Italia e la Francia 15 aprile 1904 per la reciproca concessione di guarentigie ed agevolezze ai rispettivi operai.

\section{Caldarini $(\bowtie)$}

Department of Education, CREIFOS (Centre of Research on Intercultural and Development Education), Roma Tre University, Rome, Italy

e-mail: c.caldarini@proximus.be 
family and economic hardship. For each of these areas, the chapter highlights the role of the main institutional actors in charge of specific social protection areas.

A special category of social actors occupies an important place in this context: the so-called Patronati institutes. As will become apparent in this chapter, Patronati have become since World War II a central institution in the field of social protection and migration policies, at home and abroad. This is a category of social actors deeply linked to the history of the Italian diaspora, as well as that of Italian trade unionism, and which is unparalleled in any other country in the world (Caldarini 2010).

\subsection{Diaspora Characteristics and Home Country Engagement}

\subsubsection{The Italian Diaspora and its Relations with the Homeland}

Historically, three major waves of Italian emigration can be identified. The first massive wave began in 1861 with the unification of Italy and ended in the 1920s with the rise of the Italian Fascism. A second wave began after the end of World War II and ended approximately in the 1970s. It marked, inter alia, the beginning of the transition of Italy from a country of emigration to one of immigration. ${ }^{2}$ A third wave, still ongoing, started in 2007, when the emigration flow started to grow again in an extraordinary way, particularly among young people. In addition to international migration, Italy has also experienced large-scale internal migration between regions, with a significant cultural, economic, social and political impact on the country (Ascoli 1979; Pugliese 2006).

Overall, it is difficult to provide exact figures on how many Italians have left their country permanently, but different estimates have been made by scholars and public institutions. King (1978) estimated that about 25 million Italians were residing outside of Italy in the 1970s. Gabaccia (2000) estimated that since 1800, over 27 million have left Italy, and more than half have returned home. However, she also argues that rather than forming a "nation without borders", Italy actually counts "many diasporas", as migrants have in fact maintained strong ties with their families and regional cultures. In 2000, the Italian Ministry of Foreign Affairs estimated that between 60 and 70 million people of Italian origin were residing abroad at the time (Caritas 2001). Lastly, the most recent official data of the Register of Italians Residing Abroad (AIRE) shows that the number of nationals residing abroad who are officially registered with Italian authorities has increased by $70 \%$ in the last 13 years, moving from 3,106,251 in 2006 to 5,288,281 in 2019 (Fondazione Migrantes 2019).

\footnotetext{
${ }^{2}$ In 1973, for the first time in Italy the migration balance became positive: 101 entries for 100 expatriates (IOM 2011).
} 


\subsubsection{Diaspora Infrastructure and Key Engagement Policies}

Over the years, Italy has built a composite diaspora infrastructure to deal with its population abroad. This infrastructure entails that a number of services are provided to citizens abroad but also that an advance form of consultation exists between the diaspora and the homeland. The main pillars of this infrastructure are the following: (1) a network of consular, cultural and educational institutions abroad, (2) a system of local consultation bodies, (3) a network of regional emigration councils, (4) a specific parliamentary representation of Italians abroad, (5) a specific governmental authority for Italians abroad and (6) a unique transnational network of welfare advice centers, called Patronati. This section discusses each one of them, along with the core missions they conduct.

First, given the importance of the diaspora, Italy has developed over the decades an important network of consular offices, cultural institutes and Italian schools abroad.

The general task of the consular offices is to protect the interests of Italians abroad and to provide them with services and assistance, for example, in cases of death, accident, serious illness, arrest or detention, natural disasters, riots, armed conflict, etc. They provide exceptional assistance and subsidies in case of "documented indigence" in the form of a "food package", a one-off cash aid or repatriation. More classically, they issue emergency travel documents, notification abroad of judicial documents, driving licenses, vehicle registrations, and provide information on home and host country social protection. Consulates also ensure the operation of the Register of Italians Residing Abroad (AIRE), a key instrument created in the 1980s that allows administrative contacts between Italians abroad and their homeland. ${ }^{3}$

Consular repatriation only concerns Italian citizens who are experiencing issues that cannot be resolved locally, in the host country. It is provided by the Ministry of Foreign Affairs, at the expense of the Treasury Department, in collaboration with the competent local authorities (prefectures, social services, etc.), only in case of "proven financial hardship". In all other instances, repatriation can occur subject to the grant of a loan that must be repaid. The consulates also provide advice and support in case of repatriation of Italian citizens deceased abroad. They provide the authorization to the Italian municipality for the burial of the body or cremated remains, and the issue of the mortuary passport. In case of certifiable state of indigence, the consulate or embassy may aid the family of the deceased by reimbursing the cost of any properly documented funeral expenses paid locally.

In addition to the actual consulates, mobile consular services are offered, and a network of honorary consulates have been established in most countries. An honorary consular office mainly deals with orientating citizens and forwarding their requests to the general one.

\footnotetext{
${ }^{3}$ Legge 27 ottobre 1988, n.470. Istituzione dell'Anagrafe e censimento degli italiani all'estero (AIRE).
} 
In liaison with the consulate network, 83 Italian Cultural Institutes (ICI) promote the diffusion of Italian culture and language throughout major cities around the world. It is their mission to organize cultural and artistic events, to manage libraries and to establish contacts between Italian and foreign cultures.

Looking at schools in particular, the network of Italian schools abroad includes: 8 state schools (Addis Ababa, Asmara, Athens, Barcelona, Istanbul, Madrid, Paris and Zurich), 43 state-authorized schools across the world, 7 Italian sections in European schools, 77 Italian sections in foreign, bilingual or international schools, and more than 200 courses in Italian language and culture and lectureships at foreign universities (Ministero degli Affari Esteri 2017).

Despite the fact that Italian emigration has started to increase again in recent years, the number of consulates and cultural institutes decreased between 2009 and 2016 by $24 \%$ and $10 \%$, respectively. Because of budgetary restrictions, 25 consulates, 9 cultural institutes and 187 educational institutions have been closed, most of them in Europe. To partially compensate this decline, honorary consulates have increased over the same period by 5\% (Ministero degli Affari Esteri 2011, 2017).

Second, Italy created in the 1980s a widespread system of consultation and representation of Italians abroad, organized at two geographical levels. At the local level, the Committees of Italians Abroad (COMITES) were established between the 1980s and 1990s. ${ }^{4}$ Each local COMITES is elected directly by Italians abroad and cooperates with its consular authority in the protection of the interests of nationals residing in the consular district. Its task is to identify the social, cultural and civil needs of the community and to promote initiatives in matters pertaining to the social and cultural life. It expresses a mandatory opinion on state funding granted to the media and to institutions and associations, concerning local activities for the benefit of nationals abroad. Depending on the number of residents, it can be made up of 12 or 18 members. More than 100 COMITES have been established all over the world, but primarily in Europe and the Americas (Ministero degli Affari Esteri 2017). The interest of Italians abroad for COMITES is however limited as demonstrated by the fact that less than $5 \%$ of the eligible voting population participated in the last election of $2015 .^{5}$

The General Council of Italians Abroad (CGIE) — established in 1989—performs, at a global level, the same function that the COMITES perform locally. ${ }^{6}$ It advises the Government and the regions on matters of major interest for Italians abroad: living conditions, education and social services, financial support for associations, information for Italians abroad, consular activities, etc. As a formal

\footnotetext{
${ }^{4}$ Legge 8 maggio 1985, n. 205. Istituzione dei comitati dell'emigrazione italiana (COEMIT); Legge 5 luglio 1990, n.172. Istituzione dei comitati degli italiani all'estero (COMITES).

${ }^{5}$ According to the Ministry of Foreign Affairs, 243,162 citizens voted in 2015, out of a total of $3,747,341(6.5 \%)$. Of these, $64.9 \%$ sent in their ballots on time, bringing the actual turnout to $4.46 \%$. The number of valid votes was 141,284 , i.e. $3.75 \%$ of the electorate. www.esteri.it/mae/it/ sala_stampa/archivionotizie/approfondimenti/2015/05/elezioni-comites-1-esito-delle.html Accessed 17 March 2020.

${ }^{6}$ Legge 6 novembre 1989, n. 368. Istituzione del Consiglio generale degli italiani all'estero (CGIE).
} 
consultative body, the opinions and recommendations that the CGIE addresses to Italian institutions (mainly Government and Parliament) may also concern social protection issues (in particular, pensions and social assistance for the most deprived). Since 1998, the CGIE's opinion has been mandatory for each act of the Government and regions concerning Italians abroad. ${ }^{7}$

The CGIE Plenary Assembly includes 65 members residing abroad, elected by the COMITES network, and 29 members appointed by the Government, following recommendations from the parties represented in Parliament, trade unions and the most representative diaspora institutions. The Minister for Foreign Affairs chairs the CGIE Assembly. In spite of this elaborate structure, the opinions of the CGIE rarely have a real impact on political decisions. For instance, since 1992, a number of recommendations have been made by the CGIE in favor of a "social allowance for poor elderly people living abroad", but the Government has never taken these into consideration (see Narducci 2014).

Third, even though immigration and emigration policies are essentially the responsibility of the central Government, regional institutions promote and finance initiatives primarily aimed at preserving and strengthening social and cultural relations between emigrants and their region of origin. To this end, during the process of decentralization and regionalization of the Italian state that took place from the 1970s through the 1990s, the 21 regions created their own Regional Emigration Councils (Consulte regionali dell'emigrazione). All the Emigration Councils are established by regional laws and only have an advisory function. Their mission is to formulate opinions, proposals and recommendations to the regional Government regarding cultural and exchange activities, social conditions, information and studies, right to study, dissemination and preservation of regional cultural and artistic heritage. They are composed of local elected officials at regional, provincial or municipal level, experts, representatives of economic organizations, trade unions and emigrant associations.

Fourthly, and this is a central and recent feature of the Italian system of representation of the diaspora, since 2001, Italian abroad have had the right to vote and stand for Italian elections without the need to return to Italy. ${ }^{8}$ Thanks to this reform, all Italian citizens over 18 years old who are registered with the Register of Italians Abroad (AIRE) can vote by post (absentee ballot) and stand as a candidate. ${ }^{9}$ This right was first used in the 2006 general elections and allowed Italian voters residing abroad to elect six senators and 12 deputies to the national Parliament, in representation of a special extra-territorial electoral constituency (Circoscrizione Estero), divided into four continental districts (see Table 16.1). Through the same system,

\footnotetext{
${ }^{7}$ Legge 18 giugno 1998, n.198. Modifiche alla legge 6 novembre 1989, n. 368, recante istituzione del Consiglio generale degli italiani all'estero.

${ }^{8}$ Legge 27 dicembre 2001, n. 459. Norme per l'esercizio del diritto di voto dei cittadini italiani residenti all' estero.

${ }^{9}$ Italian citizens residing abroad can also return to Italy to vote. No provisions are made for refunding the travel expenses of those who have opted to vote in Italy.
} 
Table 16.1 Composition of the Foreign Constituency (Circoscrizione Estero)

\begin{tabular}{l|l|l|l|l}
\hline Continental districts & $\begin{array}{l}\text { Italians residing } \\
\text { abroad }\end{array}$ & $\begin{array}{l}\text { Italians residing abroad } \\
\text { eligible to vote }\end{array}$ & Deputies & Senators \\
\hline Europe & $2,685,815$ & $2,261,416$ & 5 & 2 \\
\hline South America & $1,559,068$ & $1,343,929$ & 4 & 2 \\
\hline North and Central America & 451,062 & 389,060 & 2 & 1 \\
\hline $\begin{array}{l}\text { Africa, Asia, Oceania and } \\
\text { Antarctica }\end{array}$ & 277,997 & 236,449 & 1 & 1 \\
\hline Total & $\mathbf{4 , 9 7 3 , 9 4 2}$ & $\mathbf{4 , 2 3 0 , 8 5 4}$ & $\mathbf{1 2}$ & $\mathbf{6}$ \\
\hline
\end{tabular}

Sources: Decreto del Presidente della Repubblica, 28 Dicembre 2017; Ministero dell'Interno

since 2001, it is also possible for Italian citizens residing abroad to vote in Italian referendums.

Given the size of the diaspora (officially more than 4, 2 million voters residing abroad) and the importance of the parliamentary seats at stake, virtually all Italian political parties have an organized presence abroad, which reproduces the same internal structure they have in Italy (clubs, committees, federations, associations, etc.). In addition to the political parties officially existing in Italy, there are also specific political parties for Italians abroad, mainly in South America. Concerning the electoral behavior of Italians abroad, Battiston and Luconi (2018) note that there is a strong divergence of interests, and therefore of political orientations, between the various generations of Italian emigrants and consequently, between historical destination countries (such as Latin America) and those in which there was a renewal of the Italian presence (Europe, United States of America). In the 2006 general elections, turnout reached $39 \%$, but the initial enthusiasm is slowly fading as turnout dropped to $29 \%$ for the last general elections held in 2018.

Fifth, over the years, different ministerial types of institutions dedicated to the diaspora have been created and have later disappeared. Between 1991 and 2006, a specific Ministry (or Department) has been the competent governmental authority for Italians abroad: the Ministry for Italians Abroad and Immigration (1991-1992), the Ministry for Italians in the World (1994-1995), the Department for Italians in the World at the Presidency of the Council of Ministers (1995-2001), the Ministry for Italians in the World (2001-2006). This competence is currently conferred to the Ministry of Foreign Affairs which means that there is no longer a specific ministry dedicated to this issue. The Ministry of Foreign Affairs includes eight Directorates General, one of which, the Directorate General for Italian Citizens Abroad and Migration Policies (DGIEPM), coordinates the policies relating to the rights of Italians abroad. Such policies include: protection and assistance; social, linguistic and educational promotion; relations with the COMITES and CGIE; funding to associations and committees; electoral services; social protection and tax advice; legislative proposals concerning Italians abroad. The Minister of Foreign Affairs is, inter alia, the president of the CGIE.

The sixth, and most innovative Italian diaspora institution compared to other European Union (EU) Member States refers to the Italian Welfare Advice Centers known as Patronati. They were created after World War II to facilitate access to 
individual rights in the field of social protection. Although the first Patronati dates back to the mid-nineteenth century as an unofficial organization, mainly to provide relief for Italian emigrants who disembarked from ships in Argentina and Brazil (Murat et al. 2008), the Patronati, as we know them today, were created in 1945 at the initiative of the General Italian Trade Union Confederation (CGIL) and the Christian Association of Italian Workers (ACLI). They are, today still, special nonprofit institutes linked to trade unions or corporative associations, providing services in the field of social protection, emigration and immigration, widespread across Italy and abroad, especially in the main destination countries of the Italian diaspora. As they are funded by a slight percentage of the compulsory social security contributions $(0.193 \%$ from 2015$)$, they are considered as "private bodies of public interest". Their services are free for all the beneficiaries and no affiliation is in fact required to access them.

The Patronati are a key factor in Italy for all persons (regardless of nationality) in accessing social protection. They also have hundreds of offices in at least 40 countries to serve the needs of Italians abroad. They provide services to national and non-national citizens having a link with the Italian social security, mainly in matters of pensions (i.e. former immigrant workers in Italy who have returned to their home country). Blurring further the distinction between public and private, in certain countries, the Patronati also provide some consular services: applying for an Italian tax code, passport and ID card, Italian citizenship applications, civil status records, AIRE registration, etc. In the countries where the Patronati are present, their services are free of charge. They help to request a home or host country benefit and also to request a benefit from another country, if one has lived and worked in several countries (provided, of course, that the Patronato has an office in this other country). Both in Italy and abroad, the Patronati operate under the authority of the Italian Ministry of Labour and Social Policies. To be more precise, each Patronato operates under a "double authority": on the one hand, the Ministry of Labour and on the other hand, the social body from which each Patronato (and its employees) depends. Each Patronato is therefore linked to a collective/corporate social body and is consequently an expression of the political and ideological orientation of the association to which it belongs (workers associations, most of the time). Currently, 25 Patronati are legally recognized in Italy, and half of these also work abroad.

As will be demonstrated below, no other country in the world has such an original organizational and institutional model that performs very advanced types of services for citizens abroad (Caldarini 2010). For their services abroad, Italian Patronati receive from the social security fund about 40 million euros a year (this figure has been declining for some years). ${ }^{10}$ More than half are allocated to the four main Patronati, related to the three major union confederations (CGIL, CISL and UIL) and to the Christian workers' association (ACLI). It is to be noted that, in practice, this budget also serves to finance other trade unions activities (De

\footnotetext{
${ }^{10}$ In 2015, the percentage of mandatory social contributions allocated to the Patronati was reduced from $0.226 \%$ to $0.193 \%$.
} 
Saintignon et al. 2005). Thanks to this system, about 600,000 citizens abroad can be helped free of charge (according to official figure from the AIRE population register, this is almost one in eight Italians abroad). At the same time, this system gives the Patronati strength and power greater than any other Italian association or organization abroad (Senato della Repubblica 2016). By way of example, every year, the Patronati manage, on behalf of the Italian National Institute of Social Security (INPS), about 200,000 tax returns, and almost 400,000 certificates of living status of Italian pensioners abroad (see below).

\subsection{Diaspora Policies and Social Protection in Italy}

The Italian social protection system is sometimes considered one of the most fragmented among EU Member States and the countries belonging to the Organization for Economic Cooperation and Development (OECD). The incidence of undeclared work, the lack of universal policies against poverty, the weak labor protection for some forms of contracts and the proportionally low social spending, mainly concentrated on pensions and older people, are historically some of the root causes of social inequality and poverty in Italy (Saraceno 2014; Zoli 2004).

Social protection policies for the diaspora should also be understood in this context. In the infrastructure described in the previous section, the Patronati are the main actors operating abroad in the field of social protection. Indeed, the consultative bodies (CGIE, regional councils or parliamentary representation of Italians abroad) do not play an effective role in terms of social protection for nationals residing abroad. The consulates, on the other hand, have only a generic function "to provide for the protection of Italian workers, particularly in terms of living conditions, work and social security". Their role is thus to ensure the link between citizens abroad and Italian social security institutions and give information to citizens. However, they have no specific task of assisting nationals residing abroad to access the home or host country benefits and their mission of information provision consists mostly in offering information on pension payments abroad or on pensioners' income declaration, but not (or rarely) on unemployment or other social protection benefits. Overall, it is a standard procedure that the consulates redirect citizens towards the Patronati, in countries where these are present.

\subsubsection{Unemployment}

Beyond the EU framework (see European Commission 2017), Italian public institutions have no specific policies, programmes or services responding to the needs of unemployed nationals residing abroad. Consulates do not have a specific role in the field of unemployment either. The only organisations financed by public money, providing information and concrete services to access home and host country-based 
unemployment benefits for Italian workers abroad, are the Patronati. One of their functions is to submit administrative documents (or other forms of administrative support) to public institutions in charge of unemployment benefits. In practice, however, citizens abroad experience that the level of service provided by the Patronati in the area of unemployment is much more limited than that provided in the area of pensions. The reason for this is that only some of the services offered by the Patronati - such as pensions - are taken into account in the calculation of the annual grant they receive from the Italian Government, while others-such as unemployment benefits - are not compensated at all. More concretely, if a Patronato successfully deals with a request for a disability pension, a score of 6 will go into the calculation of the total annual funding that the Italian state will pay to this Patronato. A retirement pension accounts 5 points. A residence permit or family reunion accounts only for 0.35 points. Other benefits, such as unemployment benefits, are worth zero points. In total, the Patronati need to treat 95 different types of social benefits and only 37 of these lead to a score between 6 and 0.35 . All the others are worth zero points and therefore do not contribute to the calculation of the annual funding.

Lastly, it is worth mentioning the existence of a special unemployment benefits scheme for workers repatriated to Italy after a period of work abroad, in EU or nonEU countries. It concerns those who have involuntarily lost their job for dismissal or non-renewal of a seasonal employment contract by the employer abroad. ${ }^{11}$ The maximum duration of this special benefit is 180 days, and the amount is about $30 \%$ of the conventional salary, according to tables established by annual ministerial decrees. In addition to being little known, even among insiders, this special unemployment benefit scheme is rarely applied because, to access it, one must return in Italy within 6 months of their dismissal, a period during which one would, more likely, continue to look for work in the host country.

\subsubsection{Health Care}

The Italian National Health Service (SSN) is residence-based and reserved for those registered with the Local Health Authorities (Aziende sanitarie locali). Outside the legal and political framework of the EU (see European Commission 2017), Italy has no specific policies to support its citizens abroad in the field of health care. Similarly, national and regional authorities have no specific activities or services to help people living abroad to address health risks or to access disability benefits, no public training, information or awareness campaigns, and consulates and any other diaspora infrastructures have no specific skills in helping nationals abroad in this field.

Only in some exceptional cases, national authorities have the task of intervening to help nationals abroad. Two possibilities exist. First, citizens registered with the

\footnotetext{
${ }^{11}$ www.inps.it/nuovoportaleinps/default.aspx?itemdir=50191. Accessed 17 March 2020.
} 
National Health System, who for work and study related reasons are living in countries outside the EU where there are no bilateral agreements on health care, can take advantage of the home country health coverage indirectly, by advancing the expenses and submitting a request for reimbursement to the Italian diplomatic representation. ${ }^{12}$ Second, as mentioned above, in case of health-related economic hardship, Italians abroad in a state of "documented indigence" can address their consulate to benefit from a "consular repatriation" at the expense of the Treasury Department. This concerns only Italian citizens who are experiencing issues that cannot be resolved locally, in the host country.

In the countries with the largest presence of Italian citizens, they can generally count on the support of the Patronati, which are specifically funded to help citizens abroad to access the Italian and host country social benefits. In these countries, the task of consulates is therefore mainly limited to the reorientation of people towards the Patronati.

With regards to the provision of information in the area of health care, it should also be noted that on the website of the Italian Ministry of Health an interactive guide ("Se parto per...") gives some information on the right to health assistance during a stay or residence in any country in the world, in particular: "how to obtain health care in another country", "how to request any reimbursement" and "who to contact". ${ }^{13}$

Lastly, regarding medical care abroad, a peculiarity of the Italian diaspora is the existence of 22 hospitals and 20 treatment centers with Italian assistance in the world. These institutions are mostly private structures, founded by associations, religious bodies and non-governmental organizations - while they may sometimes receive financial support - that do not directly depend on Italian institutions. Their creation is often related to the history of emigration (e.g. in Latin America), colonial history, religious congregations or university cooperation and therefore were not always founded with the objective of responding to the needs of Italians abroad.

\subsubsection{Pensions}

As explained earlier, the Italian authorities entrust the Patronati with the task of helping Italian pensioners abroad to access their right to a pension whether it concerns a pension paid by Italy or one paid by the country of residence. The Patronati have direct access to the main databases of the Italian social security system and can therefore carry out numerous tasks for citizens abroad in this area. For instance, they can deliver life certificates, transmit tax returns, verify payments, check social insurance contributions, apply for pensions under international agreements,

\footnotetext{
${ }^{12}$ Decreto del Presidente della Repubblica 31 luglio 1980, n. 618.

${ }^{13}$ www.salute.gov.it/portale/temi/p2_4.jsp?lingua=italiano\&area=Assistenza\%20sanitaria. Accessed 17 March 2020.
} 
calculate the contribution periods in different countries (i.e. aggregation), export social security benefits, claim for survivors' pensions, redress decisions taken by the pension institutions, etc. Also, it is important to note that the Patronati's support materializes via delegation of the interested party, meaning that they can carry out in his/her name all the practices, including legal disputes if necessary.

In 2016, the Italian National Institute of Social Security (INPS) paid 373,265 pensions abroad. The total expenditure exceeds one billion euros (CSRIP 2018). Sixteen percent of pensions paid abroad (i.e. almost 60,000) are the result of fully paid contributions in Italy: they are therefore pensioners who have chosen to leave Italy to reside in another country, in many cases due to the cost of living and tax benefits. Seventy-five percent of the expenditure for pensions paid abroad is concentrated in the ten countries in which the greatest flow of emigration of workers from Italy occurred in the last century (Table 16.2). Most of the activities (and the money flows) of the Patronati abroad are also concentrated in these ten countries.

In order to pay pensions abroad, INPS uses the services of a bank, which gets awarded a three-year public contract. Among other things, the assigned bank has the task of annually verifying the pensioner's living status, address and residence. As from 2012, the bank designated is Citibank. Concerning life certificates, Citibank yearly mails to each Italian pensioner abroad a "Life Certificate Form". The pensioner then completes this form with a certified signature and sends it to the bank. The Life Certificate Form may be authenticated by an official from the Italian consulate or embassy, or alternatively, by a municipal officer or a notary.

As mentioned previously, pensions are the social protection area where the Patronati are most eager to intervene as they are best financially compensated for this type of service. Yet, this was not the initial mission of the Patronati as originally, between 1940 and 1960, they served mainly to help active workers (accidents at work, occupational diseases, unemployment, etc.).

Table 16.2 Countries with the highest number of Italian pensions paid abroad in 2016

\begin{tabular}{l|l|c}
\hline & $\begin{array}{l}\text { Number of } \\
\text { pensions }\end{array}$ & Total expenditure $€$ \\
\hline Canada & 57,215 & $76,375,147$ \\
\hline Australia & 47,529 & $90,580,246$ \\
\hline Germany & 47,273 & $90,024,260$ \\
\hline France & 44,971 & $100,179,082$ \\
\hline USA & 39,036 & $97,734,086$ \\
\hline Switzerland & 30,649 & $81,574,387$ \\
\hline Argentina & 25,938 & $95,907,561$ \\
\hline Belgium & 14,714 & $33,769,715$ \\
\hline UK & 10,795 & $27,712,802$ \\
\hline Brazil & 8030 & $39,816,869$ \\
\hline
\end{tabular}

Source: CSRIP 2018 


\subsubsection{Family-Related Benefits}

Among all social expenditures, the one related to family benefits is by far the least important one in Italy's welfare budget (about $4 \%$ of the total social spending). Three different types of family benefits should be mentioned: (1) the Household Allowance (Assegno per il Nucleo Familiare), for families of employees and retired employees who have an income lower than that established annually by law; (2) the Local Authority Allowance (Assegno dei comuni) for low-income households with at least three minor children, granted exclusively through the local authorities; and (3) the Family Allowance for Pensioners (Assegni familiari ai pensionati), for families of former self-employed workers (craftsmen, traders and farmers). While the first two benefits are subject to the residence principle and are not exportable, the Family Allowance for Pensioners can be paid to pensioners residing abroad. In this case, the Patronati are also given the task of helping Italians abroad to access this benefit.

\subsubsection{Economic hardship}

A minimum income, on a national scale, was established for the first time in Italy by the Stability Law of 2016. This new scheme, called Reddito di inclusione (Inclusion Income), has been approved in March 2017, and is in effect only since December 2017 with a limited budget of EUR 1.5 billion. One of the conditions for accessing this scheme was to be resident in Italy for at least 2 years continuously. This Inclusion Income provision did not therefore apply to citizens residing abroad.

In January 2019, Italy introduced two new minimum income schemes called Reddito di cittadinanza (Citizenship Income) and Pensione di cittadinanza (Citizenship Pension). ${ }^{14}$ According to the Government's forecasts, when fully implemented, these two social benefits should concern about 5 million potential beneficiaries, with a total spending of around 6 billion euros a year. ${ }^{15}$ As in the case of the Inclusion Income, these two new minimum income schemes do not apply to citizens residing abroad. In addition, the beneficiary must have been resident in Italy for at least 10 years. This last condition was included to limit the benefits for immigrants residing in Italy, but has the associated side-effect of also excluding Italians who return to Italy after a period of residency abroad, even a short one. They, too, need to comply with the 10 years residency criteria.

\footnotetext{
${ }^{14}$ Decreto-Legge 28 gennaio 2019, n. 4. Disposizioni urgenti in materia di reddito di cittadinanza e di pensioni.

${ }^{15}$ According to INPS data for January 2020, just over 1 million households, corresponding to 2.5 million people, receive the citizenship income or pension. The average monthly amount is $€ 493$ per household.
} 
Besides this scheme and as mentioned previously, there is also a cash benefit for Italians abroad "in a state of documented indigence" that can be obtained via the consulate. It is an "absolutely exceptional" cash aid, annually determined by the Ministry of Foreign Affairs, and/or a cash loan, due to unexpected economic difficulties and the impossibility of using the help of family members or third parties. Only the cash loan must be repaid. The "state of documented indigence", and so the need to repay, or not, the cash aid, must be evaluated by the consulate on a case-bycase basis, according to criteria annually defined by the Ministry of Foreign Affairs. These temporary cash aids are offered to nationals residing both inside and outside the EU, but it is most frequently applied in Latin American countries (Narducci 2014). They are primarily aimed at poor citizens who are not entitled to any social benefit, either from their home or host country.

\subsection{Conclusions}

The Italian diaspora is a large-scale historical phenomenon that has involved millions of people for at least a century and a half. To manage and, initially, encourage emigration, Italy has built throughout the years a composite diaspora infrastructure. Over the last 40 years, Italy has attached great importance to the representation and consultation of nationals abroad. But probably the most important policy for Italians abroad, and in any case the most relevant one in the social protection field, from the end of World War II to today, was the creation of the Patronati, by the trade unions, in 1945, and their official recognition in 1947 as "private bodies of public interest". ${ }^{16}$

Italy is not the only country where private organizations linked to trade unions are funded to carry out functions of public interest in the field of social protection. Well-known examples are Belgium, Denmark, Finland and Sweden, where trade unions manage unemployment insurance (the so-called "Ghent system") (Scruggs 2002). But Italy is the only country in the world to have created bodies to make social protection accessible to its citizens abroad. Moreover, unlike any other country, the services provided by the Italian Patronati are free for all, without any membership requirements, and, in theory, cover all areas of social protection (Caldarini 2010).

In all the countries where the diaspora is significant, the Patronati are present and cooperate closely with consulates and embassies. In some countries they often provide some consular services (consular correspondents), especially in the regions where the general consulates have been closed. The Italian law provides, in fact, that the Patronati must also carry out support activities for Italian diplomatic and consular authorities abroad. It is also a standard practice that the consulates redirect towards the Patronati for any social problem related to pensions, social protection,

\footnotetext{
${ }^{16}$ Decreto legislativo del capo provvisorio dello Stato 29 luglio 1947, n. 804. Istituti di patronato e di assistenza sociale.
} 
social assistance, repatriation, indigence, freedom of movement and residence, etc. All this allows them to have a voice on consular and diplomatic policies. In other words, while they are not a direct representation of the state abroad, the Patronati conduct a series of missions that the state would usually take charge of.

Because of its central role in the life of many Italians residing abroad, the Patronati are also a key political player in relation to the diaspora. Its voice weighs considerably on the election of the members of the COMITES and CGIE. Similarly, during electoral campaigns for the seats allocated to the Foreign Constituency (Circoscrizione Estero), the actions of the Patronati has an influence on the vote of citizens abroad, especially older people, and many candidates from these institutions. In this regard, it should be recalled that in the 2006 general elections, the vote of Italians abroad determined the victory of the center-left coalition (led by Romano Prodi) which defeated the center-right (Silvio Berlusconi) by several thousand votes, thanks only to the results in the Circoscrizione Estero.

Although most Italians abroad do not know or do not use Patronati, especially among the young and the most qualified, they are certainly an important network of protection, participation and solidarity. For people with more difficulties (such as isolated seniors and people who cannot read or write), the Patronati are sometimes a last safety net. Overall, it can be argued that the Patronati have become fairly powerful. For this reason, using the pretext of austerity, several political parties and lobbies have been calling for some years for their closure or reduction in number. A popular referendum on the abolition of funding and legal recognition of the Patronati had been promoted by some political forces in 2000 , but it was rejected by the Constitutional Court. This was probably one of the reasons why the last stability laws reduced funding and some free services will have to gradually become paid for.

In this context, it is worth considering what would happen if the Patronati were further downsized or, as some ask for, drastically closed. We have already seen that the Italian social protection system is particularly fragmented and weak. Social expenditure is low and focused on old-age pensions. The Patronati, which were born to help mainly active workers (for accidents at work, occupational diseases, unemployment, etc.) and those who emigrated in search for work (therefore young people), have gradually become, in the last decades, "services for the elderly" above all (old-age pensions, survivors' pensions, etc.) and are finding it increasingly difficult to intercept the new forms of the Italian diaspora, especially young, skilled and atypical workers (Caldarini et al. 2014).

Because of the Patronati's quasi-monopoly in dealing with citizens abroad, one can wonder, after all, if their position has weakened all other diaspora infrastructures. As shown in this book, in other EU countries, consulates and public social security institutes directly and effectively carry out policies and services facilitating access to social protection for nationals residing abroad. In these countries, a service like that of the Patronati have no reason to exist (Caldarini 2010). Yet, in the current Italian context, characterized by the reduction of consular services, the downsizing, or even, as some plead for, the closure of the Patronati, would significantly impact citizens abroad. The question now is whether it is more appropriate to reform, restructure, consolidate or secure the existing heritage and its wealth of experience, or, in order to rebuild, to first remove the rubble. 
Acknowledgements This chapter is part of the project "Migration and Transnational Social Protection in (Post)Crisis Europe (MiTSoPro)" that has received funding from the European Research Council (ERC) under the European Union's Horizon 2020 research and innovation programme (Grant agreement No. 680014). In addition to this chapter, readers can find a series of indicators comparing national social protection and diaspora policies across 40 countries on the following website: http://labos.ulg.ac.be/socialprotection/.

I wish to thank Mara Caldarini for her constructive linguistic advice. Responsibility for any inaccuracies remains mine.

\section{References}

Ascoli, U. (1979). Movimenti migratori in Italia. Bologna: Il Mulino.

Battiston, S., \& Luconi, S. (2018). Autopsia di un diritto politico. Il voto degli italiani all'estero nelle elezioni del 2018. Torino: Centro Altreitalie, Accademia University Press.

Caldarini, C. (2010). Dire, fare, tutelare. L'azione sindacale di tutela individuale in cinque paesi europei. Roma: Ediesse.

Caldarini, C. (2014). Il coordinamento dei sistemi di sicurezza sociale in Europa. Ovvero, perché in Europa i regimi di welfare sono così diversi tra loro. In Vv.Aa. Il manuale dei diritti sociali (pp. 79-86). Roma: Ediesse.

Caldarini, C., Giubboni, S., \& McKay, S. (2014). The "place" of atypical work in the European social security coordination: A transnational comparative analysis. Catania: WP C.S.D.L.E. "Massimo D'Antona" Collective Volumes..

Caritas. (2001). Dossier statistico Immigrazione. Roma: Anterem

CSRIP. (2018). Il bilancio del sistema previdenziale italiano. Rapporto n.5. Milano: Itinerari Previdenziali.

De Saintignon, P., Guedj, J., Osterrieder, H., \& Saintoyant, V. (2005). Étude d'administration comparée sur le financement des syndicats (Allemagne, Belgique, Grande Bretagne, Italie, Suède). Paris: Igas.

European Commission. (2017). Your social security rights in Italy. Brussels.

Foerster, R. F. (1919). The Italian emigration of our times. New York: Harvard University Press.

Fondazione Migrantes. (2019). Rapporto Italiani nel Mondo. Todi: TAU.

Gabaccia, D. R. (2000). Italy's many diasporas. London: UCL Press.

IOM. (2011). Migration in Italy. Current situation and perspectives. Rome: Idos.

King, R. (1978). Report: The Italian diaspora. Area, 10, 385.

Ministero degli Affari Esteri. (2011). Annuario Statistico 2011. Roma: Sistema Statistico Nazionale.

Ministero degli Affari Esteri. (2017). Annuario Statistico 2017. Roma: Sistema Statistico Nazionale.

Murat, M., Pistoresi, B., \& Rinaldi, A.. (2008). Italian diaspora and Foreign direct investment. Paper. March 28-30. University of Nottingham.

Narducci, F. (2014). Povertà e indigenza degli italiani all'estero. Rapporto italiani nel mondo 2014 (pp. 298-307). Fondazione Migrantes. Todi: TAU.

Pugliese, E. (2006). L'Italia tra migrazioni internazionali e migrazioni interne. Bologna: Il Mulino.

Saraceno, C. (2014). Da dove partire per la riforma del welfare. lavoce.info. www.lavoce.info/ archives/30291/dove-partire-per-riforma-welfare. Accessed 17 Mar 2020.

Scruggs, L. (2002). The Ghent System and Union Membership in Europe, 1970-1996. Political Research Quarterly, 55(2), 275-297.

Senato della Repubblica. (2016). Indagine conoscitiva sulla riforma dei patronati italiani che operano fuori dal territorio nazionale per le comunità italiane residenti all'estero.

Zoli, M. (2004). I sistemi di welfare state nei paesi dell'Unione Europea. LLEE Working Document. No.1 January. 
Open Access This chapter is licensed under the terms of the Creative Commons Attribution 4.0 International License (http://creativecommons.org/licenses/by/4.0/), which permits use, sharing, adaptation, distribution and reproduction in any medium or format, as long as you give appropriate credit to the original author(s) and the source, provide a link to the Creative Commons license and indicate if changes were made.

The images or other third party material in this chapter are included in the chapter's Creative Commons license, unless indicated otherwise in a credit line to the material. If material is not included in the chapter's Creative Commons license and your intended use is not permitted by statutory regulation or exceeds the permitted use, you will need to obtain permission directly from the copyright holder.

(c) (i) 